\title{
WPS3599
}

\section{Core Indicators for Determinants and Performance of the Electricity Sector in Developing Countries}

\author{
Tooraj Jamasb ${ }^{a b}$ \\ Department of Applied Economics, University of Cambridge
}

David Newbery

Department of Applied Economics, University of Cambridge

Michael Pollitt

Judge Institute of Management, University of Cambridge

World Bank Policy Research Working Paper 3599, May 2005

The Policy Research Working Paper Series disseminates the findings of work in progress to encourage the exchange of ideas about development issues. An objective of the series is to get the findings out quickly, even if the presentations are less than fully polished. The papers carry the names of the authors and should be cited accordingly. The findings, interpretations, and conclusions expressed in this paper are entirely those of the authors. They do not necessarily represent the view of the World Bank, its Executive Directors, or the countries they represent. Policy Research Working Papers are available online at http://econ.worldbank.org.

\footnotetext{
a This paper was prepared as part of the research program on Industrial Organization Policy for Development at the Development Research Group of the World Bank. We also acknowledge the support of the CMI Electricity Project (IR-45). We thank Ioannis Kessides, Paul Joskow, and Jon Stern for their valuable comments and Beth Morgan for editorial assistance.

${ }^{\mathrm{b}}$ Corresponding author. Department of Applied Economics, University of Cambridge, Sidgwick Avenue, Cambridge CB3 9DE, United Kingdom. Telephone: +44-1223-335271, Fax: +44-1223-335299, Email: tooraj.jamasb@econ.cam.ac.uk
} 


\begin{abstract}
Since the early 1990s, substantial resources and efforts have been spent on implementing market-oriented electricity reforms in developing countries. While there are important sectoral, economic, and social dimensions involved in electricity reform, empirical analysis and evaluation of reforms have been of limited use for testing the economic rationale of reforms and policy advice. This may partly be attributed to a lack of generally accepted and measured indicators for monitoring the progress, impacts, and performance of reforms. In this paper we propose a set of indicators as a first step toward filling this gap and developing a coherent framework for studying electricity reform in developing countries that covers resource and institutional endowments, key reform steps, market structure, performance, and various impacts.
\end{abstract}

Keywords: Electricity, reform, developing countries

JEL Classification: L52, L94, Q48 


\section{Introduction}

The aim of this paper is to propose a framework and a set of core indicators for analysing electricity sector reform in developing countries. A review of the literature (Jamasb et al. 2004) concludes that rigorous empirical and policy-relevant evidence on the performance and determinants of electricity reform in these countries is rather limited. The evidence that is available is derived from different models, varying indicator and variable definitions, and exclusive data sets making solidifying and extension of these empirical studies difficult. In addition, the robustness of some of the empirical evidence is unclear requiring further careful data analysis, model specification and sensitivity analysis (see e.g. Mukherjee et al., 1998; Leamer 1983; 1985).

The proper study of economic reform requires an analysis of its impact and an assessment of the role of those factors that were influential in determining its outcome. Any such analysis generally involves measuring (and thereby quantifying) specific aspects of cause and effect. Almost invariably, this involves using both quantitative and qualitative indicators.

Infrastructure industry liberalisation is a key part of the economic reform agenda. Electricity reform affects industry structure, governance and ownership and has a significant impact on its economic, social and environmental dimensions. It is, therefore, important to assess the impact of reform and its determining factors. However, although there have been attempts in recent years to develop indicators in sustainable development, agriculture, environment and health, notably by international organisations, far less attention has been paid to the development of appropriate indicators for infrastructure industries reform in general and electricity sector in particular (see e.g. UN, 2001; Bossel, 1999; OCED, 2002; IAEA-IEA, 2002; von Schrinding, 2002; Atkinson et al., 2002). 
Indicators reflect or represent the state of a phenomenon in the form of information. At the same time, indicators do not exist in isolation. Rather, they are often part of larger systems within which they assume their meaning. This system or framework may be presented in the form of more or less formal models. The following definition of an indicator in OECD (1993) is relevant here: "A parameter, or a value derived from parameters, which points to/provides information about/describes the state of a phenomenon/environment/area with a significance extending beyond that directly associated with a parameter value”.

Indicators, as simple measures or parts of a formal model, help in understanding complex issues and systems that otherwise could be constrained by bounded rationality. Although indicators have an important role in forming our understanding, simplification inevitably involves a degree of abstraction and loss of information. In formal models where the indicators become variables and interact with other variables to help determine the outcomes, this issue is of great importance. It is only recently that the indicators themselves have become the subject of inquiry.

The few studies that have attempted to develop indicators for electricity reform have tended to focus on developed countries. For example, DTI (2000) defines a set of indicators of electricity and gas liberalisation for European countries, and CAEM (2002) develops an index for retail competition in the US electricity sector. A notable exception is Bacon (1999) who defines and surveys some key steps in electricity reform for a large number of developing countries.

There are some key differences between developed and developing countries that have to be taken into account, namely:

i. The expected direction of price changes in developed and developing countries are often different. In many developing countries, residential customers are subsidised by industrial users while the reverse holds in some developed countries. Consequently, the expected direction of price changes from reform depends on the starting point. 
ii. Developed market economies (DMEs) and transition economies have nearcomplete electrification but in many developing countries large rural and some urban groups are not connected to the electricity supply.

iii. In many developing countries, technical and non-technical energy losses in the transmission and distribution networks are high compared to DMEs.

iv. In many developing countries, the high level of non-payment has an adverse effect on the financial health of the sector.

v. In many developing countries, capacity shortages, poor utilisation of existing capacity and unserved demand result in significant economic loss.

vi. In developing countries, regulatory credibility, institutional weaknesses and political interference are more important drivers of private investment in the sector than in developed countries.

This paper develops a framework and a set of core indicators for electricity sector reform in less developed countries (LDCs) that can help facilitate reform representation and comparison. A common reference framework also increases comparability of analysis and knowledge. Section 2 discusses the desirable properties of indicators, Section 3 explains the criteria for indicators, Section 4 is a conceptual discussion of the framework and typology of indicators, Section 5 presents the core indicators for electricity sector reforms and Section 6 contains the conclusion and possible directions for future work.

\section{Properties of indicators}

Electricity sector reform involves various sectoral, economic, social and environmental dimensions. In order to capture and represent the many dmension of reform, a variety of indicators must be identified, defined and then measured within the proper context. This section briefly discusses the main properties of these indicators and some related issues. 


\section{Measurement unit}

Different aspects of electricity reform need different units of measurement. Most technical aspects are based on generally accepted conventions and are relatively easy to measure, but difficulties can arise in defining system parts and system levels. For example, voltage cut-off points between and in transmission and distribution networks vary across countries.

All economic and financial indicators, e. g. costs, prices, investment, are measured in some form of monetary unit. Availability and quality of such data can be low in many developing countries, and the sectoral restructuring that results in the dissolution of old entities and appearance of new ones makes much of the historical data incompatible or redundant. In addition, differences in accounting standards and inflation, as well as conversions using exchange rates and purchasing power parities, tend to reduce the usefulness of time-series and cross-country data.

Some aspects of electricity reforms are, however, not readily quantifiable in physical or monetary units. Some common reform steps, such as introducing wholesale generation markets or establishing independent regulatory agencies, fall into this category. The main issue is that simple observation of the fact that such steps been have taken does not reflect their characteristics and extent. In addition, objective comparisons across countries are inherently difficult. Qualitative aspects of the steps are, however, often the crucial factor in determining the success or failure of reform, but representation of qualitative indicators tends to involve a degree of subjective evaluation and judgement.

Subjective evaluations of complex phenomena can result in misrepresentation. The main electricity reform measures, such as privatisation, unbundling of functions, wholesale markets and independent regulation, are generally established gradually and have a qualitative dimension. Accounting for these measures with the use of dummy variables, as is sometimes done, does not reflect extent or intensity. For example, privatisation may be better represented by the percentage of energy generated or delivered by privatised firms. Also, the degree of competitiveness in wholesale electricity markets varies with the type and design of these markets. A practical 
approach has been to construct indicators that reflect the different states that an indicator can assume and then to rank them using an intensity measure. Different wholesale generation markets, such as a single-buyer with long-term contracts, voluntary spot markets, and compulsory markets with demand participation, may be ranked according to their perceived degree of competitiveness using an index that ranges from one to four. Such an approach is a reasonable representation of the market characteristic the variable is intended to measure. But, to increase confidence in the findings, sensitivity analysis involving subjective measurement of variables may still be needed in quantitative analysis.

To reduce the number of dimensions of the phenomena being studied, it is possible to merge several partial indicators to create fewer, more general ones. For example, a reform index may be constructed by assigning values to commonly implemented steps such as restructuring, competition, privatisation and regulation steps, and then combining these into a composite indicator. A notable example of such a composite indicator is found in Bacon (1999): countries are assigned one score for each of the main reform steps and their sum is used as a measure of the extent of reform. The EBRD's Transition Reports have taken this to an even more advanced level with a variety of performance measures (legal, institutional, regulatory, etc) (see EBRD, 2001).

\section{Indicators as proxies}

Reform indicators can assume different roles depending on the particular setting or type of analysis in which they are used. For example, the extent of reform expressed as an index may be the result of the quality of economic management or a country's institutional endowment; the same indicator could also be used as the determinant of a performance measure or indicator.

In addition, indicators are often used as proxies for aspects of reforms that are not directly observable and can be interpreted in a variety of different ways, e. g. levels of electricity demand or generating capacity generally represent the size of the sector, but total installed generating capacity (publicly and privately-owned) has been used as 
proxy for private investments in reformed sectors (Bergara and Spiller, 1997). Also, where there are extensive electrification programs, consumption may be interpreted as proxy for access to service. Indeed, industrial consumption has been used as a proxy for political influence (see Zelner and Henisz, 2000). Ultimately, appropriateness and accuracy of findings based on proxy indicators depend on the extent to which the indicators represent reality.

\section{Stock vs. flow indicators}

Electricity sectors are dynamic systems that respond to factors such as demand growth, availability of new technologies, compliance with environmental regulations and policy change; reforms reshape the sector by introducing new processes and new dynamism.

Within this context, reform indicators may be classified as stock or flow. For example, the efficient level of installed generation capacity, transmission and distribution networks can only be achieved and maintained through investment and maintenance expenditure (flow) and new capacity (stock). Some reform measures take time to take full effect, e. g. regulatory commitment and credibility can be thought of as stocks built up over time.

A related and but different type of indicator are those that reflect the rate of change in a measure. Some activities in the electricity sector such as generation capacity and number of customers tend to increase over time. The djective of reforms is often to accelerate the rate of change in these variables. Such changes are generally best measured by rate of change indicators. However, despite their potential use, such indicators have not yet been used in electricity reform studies.

\section{Criteria for selection of indicators}

\section{Measurability}

For an indicator to be useful it needs to be based on a clear definition and to be measurable. This is equally important whether it is expressed in physical, monetary or 
qualitative terms. But even when the relevant aspect of reform is defined, the properties of some issues make them inherently difficult to measure, e. g. the degree of a regulator's independence. Proxy indicators such as regulator's budgetary independence or the number of issues over which he or she has full discretion may be used to represent these aspects.

\section{Comparability and consistency}

Some indicators refer to an absolute or relative benchmark, e. g. privatisation may be expressed as a percentage of total assets. When measured over a period of time, the same indicator reveals information about the progress of the program. For this reason, comparability of the indicator measured over time is an important criterion; an indicator should be consistent in definition, measurement method and data assembly.

A similar argument applies to cross -sectoral comparisons, but here other issues such as technical standards and institutional characteristics, are also important. Comparison of monetary indicators can also be difficult because of differences in accounting rules and economic conditions such as inflation. In addition, the problems of conversion into a single monetary unit (e.g. Year 2000 US dollars) using currency exchange rates (or purchasing power parity rates) and suitable price deflators are non-trivial and familiar.

\section{Data and aggregation level}

Data should be available at realistic and reasonable levels of cost and effort, and sources should be reliable and, ideally, cross-checked. Care should be taken to ensure that consistency and continuity of data is maintained.

The appropriate level of disaggregation will depend on the question being asked. For example, investment or energy loss data concerning different segments are useful for different purposes. In addition, data on price, consumption and income levels for different customer groups are often necessary to investigate the distributional effect of reforms. Firm-level analysis can shed light on aspects of electricity reform. In the absence of comprehensive or specific type of data for the whole sector, firm-level analysis can prove useful. For example, Delfino and Casarin (2001) examine the welfare 
impacts of the privatisation program in Gran Buenos Aires area in Argentina using a family expenditure survey of about 5,000 households. Also, firm-level data are far more suitable for comparative efficiency analysis of identifiable units such as distribution utilities within or across countries. ${ }^{1}$

\section{Essentiality and complementarity}

Collection and analysis of the range of data needed for a thorough study of electricity reform requires an efficient allocation of limited data. Therefore individual core indicators should reflect useful information that is essential to the evaluation of some important aspect of reform. When identifying and defining the core indicators, it is important to view them as part of a wider system with various inter-relationships and feedback loops. While an individual indicator provides insight into some essential aspect of reform, the core indicators should collectively represent the reform system, plus the broader framework within which it resides and operates.

\section{Reform model and typology of indicators}

\section{Framework for analysis of electricity sector reforms}

Electricity sector reforms are multi-faceted activities with inte racting factors and a variety of impacts. The process generally involves a set of concrete steps or measures based on a specific model of reform. At one level, these measures involve structural and organisational changes to the industry, and at another level there is a requirement for appropriate institutional arrangements such as legislation and new agencies.

In addition, sector endowments and characteristics such as size, resource mix, historical development, define the initial market structure and starting point and can influence the reform path and outcome. Market structure is then influenced by various measures, such as unbundling of vertically integrated enterprises, as well as institutional factors such as regulatory authorities and legislation.

\footnotetext{
${ }^{1}$ See e.g. Jamasb et al. (2003) for a review of the use of efficiency studies of electricity utilities in developing countries.
} 
The multi-faceted nature of reform results in a variety of outcomes so effectiveness and impact can be measured through different performance indicators, e. g. operating efficiency or increased investment. There can also be linkages between sectoral performance and the driving forces that trigger reform. These forces can be internal (e.g. poor sector performance) or external (e.g. foreign debt). Figure 1 illustrates the main aspects of reforms and their inter-relationships.

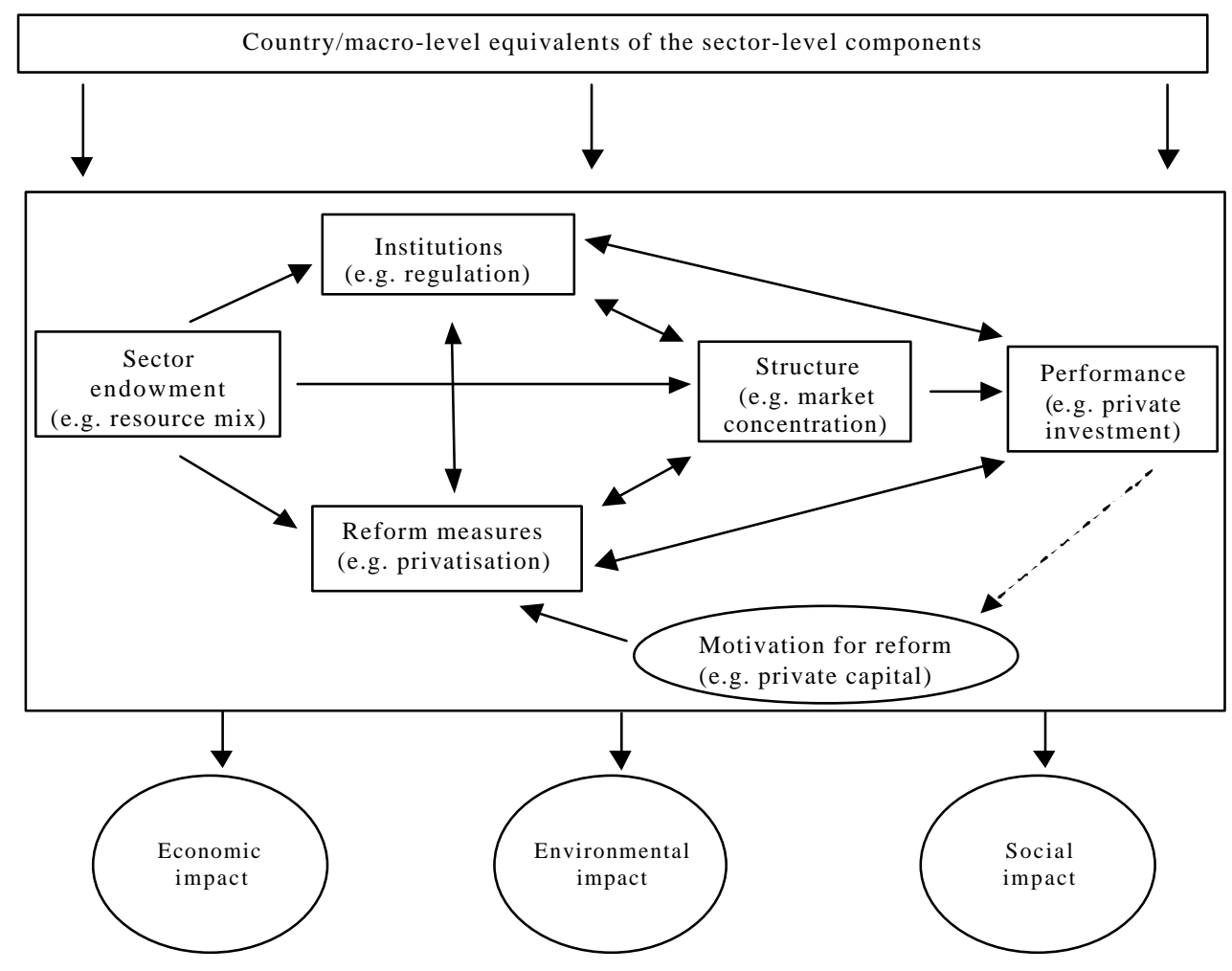

Figure 1: A model of electricity sector reforms

It is noteworthy that each of the components of this sector-level reform model can be thought of as having a counterpart in a higher or country-level model of an economy. This model is broadly along the lines of the structure-conduct-performance paradigm of industrial organisation. The remainder of this section outlines these aspects of reform in some detail and is heavily based on Jamasb et al. (2004). 


\section{Motivation for reform}

Actual reform steps, their sequence, and ultimately the reform performance, may be influenced by the motives (e.g. privatisation proceeds) behind the decision to reform. High electricity price levels may be an important driving force. Joskow (1998) points out that, in the US, states with the highest electricity prices were most likely to implement reform. The main differences in reform issues, in both developing and developed countries, are often rooted in the determinants and driving forces behind reform.

In developing countries, the macroeconomic crisis of the 1980 s created the need for a regime of fiscal responsibility. A combination of high levels of inflation, increasing debt burden and deterioration of the quality of public services, spurred political support for the liberalisation of infrastructure industries. Tariffs kept artificially low for anti inflationary purposes meant that electricity utilities' self-financing capacity was increasingly eroded during the 1980s, affecting both investment and quality of service. Privatisation would improve not only the financial health of the sector, but would also increase revenue for state treasuries, so helping to reduce and restructuring public debt. In addition, new investment would be undertaken by the private sector.

The need to ensure expansion of capacity is of special importance to less developed countries where there are 1.7 billion people without access to electricity (WRI, 2002), and social and environmental considerations need to be integrated into reform design. The pressure for reform from donor agencies also reinforced the move towards liberalisation.

\section{Key reform measures}

The electricity industry is a network comprising separate but connected and closely co ordinated, potentially competitive and natural monopoly activities. Also, his torical development, institutional features and the resource characteristics of power sectors can differ considerably across countries. Although there is a substantial variability in 
individual reforms, they generally involve a combination of the following key elements (see e.g. IADB, 2001; Joskow, 1998; Newbery, 2002):

i. Corporatisation of state-owned utilities;

ii. Enactment of an electricity reform law;

iii. Regulatory reform, including adoption of incentive regulation for the natural monopoly network activities;

iv. Establishment of an independent regulator;

v. Unbundling of vertically-integrated utilities into generation, transmission, distribution and supply activities, and where necessary horizontal splitting;

vi. Provision of third party access to networks;

vii. Establishment of a competitive wholesale generation market;

viii. Liberalisation of the retail supply market;

ix. Privatisation of electricity assets;

x. Definition of rules concerning consumer protection, allocation of energy subsidies, and stranded costs.

A World Bank survey on the state of energy reform in developing countries focused on six key steps: (i) corporatisation or commercialisation of the core utility; (ii) enactment of an 'Energy Law'; (iii) establishment of an independent regulatory authority; (iv) restructuring of the core utility; (v) private investment in greenfield sites; and (vi) privatisation (Bacon, 1999). The survey suggests a logical sequence of reform steps in which the most common (because logically the first) step is corporatisation and commercialisation of the publicly owned utility, and the least common (or logically final) step is privatisation. It should be noted that not all the above reform elements will be appropriate in all countries. For example, a particular issue that arises is whether smaller systems require vertical separation and third-party-access.

\section{Market structure}

In our conceptual model of reform, the market structure component refers to the wider framework within which the interaction of supply and demand for electricity takes place. Market structure at the time of reform is the result of the historical development 
of the sector, resource endowment and past policies. The initial structure of the sector defines the starting point for reform and is, therefore, regarded as a given factor. Same of the main features of market structure are the composition of demand for electricity, degree of vertical integration, market concentration, production technologies and degree of market opening.

In the course of the reform process, the initial market structure is subject to changes induced by the various reform measures and institutions within the sector. Sectoral structure has a direct impact on the behaviour of market actors and consequently on performance. Changes in the structure can take time to implement and are often opposed by vested interests. It is, therefore, important that the appropriate design is envisaged from the start. At the same time, shortcomings in the structure may increase the need for intervention and rules that tend to be imperfect substitutes and increase uncertainty.

\section{Institutional factors}

Institutional factors refer to the sector-level legal and regulatory frameworks that influence and support continuity of reform. An electricity act or law is generally recognised as a prerequisite for implementation, and most marketoriented reforms involve establishing independent regulatory agencies for overseeing the functioning of the sector and for protecting the rights of consumers.

Effective regulatory practice requires clarity of the regulator's mandate and clarity of the rules defining their relationship with other bodies, such as the competition commission (or anti-monopoly agency) and relevant ministries. The degree of independence and the powers of the regulators to perform their tasks are often interpreted as an indicator for political commitment to the reform process on the part of the decision-makers.

\section{Sector endowments}

Specific reform measures and some aspects of market structure and the institutional framework may be chosen as variables. However these choices, and ultimately the sector performance, are also influenced by the sector's endowments. Factors such as the 
size of the system, generation technologies (particularly hydroelectric resources), availability of domestic fuel, interconnections and geography can influence and constrain options and choices.

\section{Sector performance}

Reform performance can be evaluated along several dimensions. Private ownership, competition, and regulatory reform should improve technical performance by improving capacity utilisation, operating efficiency, labour productivity and energy losses. A key motivation for reform in developing countries is to attract private capital to reduce the burden on the general budget and to accelerate the pace of investme nt in new capacity. Domestic and international private investment, as well as public investment, will indicate the extent to which this is achieved and also indicate the significance of private sector participation.

Price changes are likely to be the most important factor for consumers, though in some countries service reliability may be even more important. Price changes measure the extent to which productivity gains have been transferred to consumers. Real price increases may not be undesirable if they had been too low and had required a subsidy. Successful reforms should improve revenue collection. The costs of an unreliable service are generally rather high so improvement in the quality of service is an important performance indicator.

\section{External reform impacts}

The electricity sector is capital intensive, crucial for economic activity and consumer welfare, and gives rise to significant environmental concerns. Changes in the structure, operation and performance may, therefore, have wide impacts, both on the environment and on the budget. The main economic impacts of reform are associated with investment. In many developing countries, demand for electricity is growing rapidly and the required investment puts a strain on public budgets. Also, the dead-weight loss associated with public funding can be relatively high (Beato and Laffont, 2002) compared to cost-recovering tariffs that allow debt financing. Private investment can 
reduce the pressure on public finance and release budgetary funds for other, more pressing, social and economic needs.

The social impact of electricity reform can be measured by welfare change resulting from price and consumption change, allowing for the public sector budgetary impact (the marginal cost of raising taxes or reducing public expenditure elsewhere). One major social benefit in poorer countries may be the extension of electrification to currently unserved groups. In addition, reforms have environmental impacts through changes in generation mix and energy use patterns. The effect of reform on fuel and technology choices can result in significant changes in emissions of greenhouse gasses and pollutants.

\section{Core electricity reform indicators}

\subsection{General}

This section outlines a wide range of indicators that reflect key aspects of the state and development of electricity reform. The core indicators, highlighted in bold, are deemed essential and represent the most important (e.g. controllable operating and maintenance costs rather than labour costs) or the preferred alternatives (e.g. number of customer minutes lost rather than the number of interruptions).

Each group of indicators also includes non-core but potentially useful indicators. Although some non-core indicators are difficult to measure, where they are available, they may be useful for in-depth and detailed studies. Some indicators can be modified to address specific issues. The organising principle for the different categories is similar to that of the individual components of the general reform model described in Section 4 and range from firm-level to high-level country factors through sector-level indicators.

The main body of core indicators are sector-specific and relate to the main aspects of reform. They also reflect some features of energy and electricity resources. Key steps 
show the extent to which the reform has been implemented against a full-scale reference model. Market structure indicators focus on the main features of the environment within which the sector operates, governance and regulatory indicators focus on ins titutional aspects of, and rules for, the oversight of the sector, and performance indicators focus on important technical, financial and social dimensions of reforms.

Firm-level indicators allow for the analysis of firm types or can be used when sectorlevel data is inadequate. Such indicators have proven particularly useful in comparative efficiency analysis of companies within a country, and across several countries. Macro level indicators represent key aspects of country-level factors that have bearings for reform implementation and performance. Impact indicators reflect the effect of reform on the wider economic, social and environmental framework within which the sector operates.

\subsection{Policy relevance of core reform indicators}

In a review of the literature, Jamasb et al. (2004) examine the existing studies based on a variety of questions and hypotheses using different methods and sets of variables. The review also outlines an array of further relevant questions that have not yet been thoroughly investigated. In keeping with the essentiality criteria, core reform indicators should be relevant to important reform issues. This subsection presents a case for a set of core indicators that can help achieve this aim.

It is important to note that the core reform indicators can be used in a variety of ways: as simple presentations of the current state of affairs, as trends over time and for comparisons. Clearly, there is a need for a well-defined, consistent and comparable set of indicators. More importantly, the indicators may also be used to answer policy and research questions or test specific hypotheses. This section is primarily concerned with the latter in more formal and structured analytical settings. Broadly, there are three approaches to analysing electricity reform: (i) econometric methods, (ii) efficiency and productivity analysis methods, and (iii) individual or comparative case studies. 
Econometric studies are best suited to the analysis of well-defined issues and the testing of hypotheses through statistical analysis of reform determinants and performance. The scope of single-country time-series and cross-section analysis is limited by the number of observation years available, and, as the main questions are related to reform determinants and the significance of various steps in the process, scope for the use of such methods is mainly within the framework of cross-country analysis.

Efficiency and productivity analyses are suitable for measuring the effectiveness with which inputs are transformed into outputs, relative to best practice. Efficiency analysis can be based on econometric techniques such as stochastic frontier analysis (SFA) and corrected ordinary least squares (COLS), or it can use non-parametric methods based on linear programming and optimisation techniques, such as data envelopment analysis (DEA) originating from operations research. Comparative efficiency analysis is most suitable where the units of analysis are whole sectors or companies. These methods have proven useful in analysis and incentive-based regulation of electricity distribution utilities, primarily in developed countries. This is largely due to the fact that the basic technical features and structures of electricity distribution systems are rather similar, making direct comparison plausible and practical.

Single or multi-country case studies are suitable when in-depth investigation or qualitative analysis is needed. This approach provides the methodological flexibility required for these types of investigations and is particularly useful for exploring processes. In addition, case studies are the obvious choice where a combination of different tasks, such as in cost-benefit analysis, is required. They may also lead to the development of hypotheses which can later be tested using more formal cross-country quantitative analysis.

In the following, we outline a selected number of important and current reform-related policy issues in the form of general research questions or hypotheses. Although the policy questions outlined here are by no means exhaustive, they do illustrate the practical relevance of the core reform indicators and their use in evaluating and 
analysing some of the most pressing issues facing reforming countries and international development agencies.

i. Higher economic and governance indicators, as well as independent regulation and cost-reflective pricing, lead to higher private investment.

Private sector investment constitutes the cornerstone of market-oriented electricity reforms. However, the marked decline in recent years of interest among international investors indicate reform vulnerability in developing countries to macroeconomic volatility and weaknesses in political and economic governance and institutions (Harris, 2003). The significance of these factors has direct policy relevance for many reforming countries and for international development organisations. This type of question can best be addressed by cross-country analysis using econometric methods. The main core indicators for the analysis with reference to the components of our reform model are investments (Table V), country-level factors (Table VII), sector regulation (Table IV), economic factors (Table VIII), and social aspects (Table IX).

ii. There is a system size below which vertical separation and competition is not effective or not worthwhile, and a level of institutional and governance endowment below which private participation is not feasible.

It is generally recognised that reform design should take the specific characteristics of the sector into account. However, this notion is often expressed in general, rather than specific terms. Two factors that characterise many reforming developing countries are small system size and very weak institutions. Countries with small systems may have inherent limitations with regards to the introduction of effective competition. Also, the poorest countries tend to exhibit the weakest levels of institutional development so are regarded by private investors as too risky or commanding high-risk premiums. This type of question may be addressed by cross-country analysis using econometric or comparative case studies. The main core indicators for this analysis with reference to the components of our reform model are market structure indicators (Table III), key reform steps (Table II) and various country-level indicators. 
iii. Diverse generation resource mix, energy independence and country institutional development are positively correlated with extent of reform.

An understanding of the importance of exogenous factors as determinants of the type or extent of reform can help in design and lead to an understanding of what measures may be feasible. This, and similar questions, can be addressed through econometric methods. The main core indicators with reference to the components of our reform model are the key reform steps implemented (Table II), resource mix and endowments indicators (Table I), and country-level indicators (Table VII).

iv. Incentive regulation and privatization improve cost and technical efficiency in electricity distribution networks.

In general, this type of analysis is best addressed through efficiency and productivity analysis at company level. These techniques are used to determine the relative efficiency of the distribution utilities. Alternatively, efficiency analysis can be used as part of the regulatory reform of distribution networks and the implementation of yardstick regulation or postreform monitoring and performance evaluation. A variety of combinations of input and output can be used. Monetary core indicators, such as controllable operating costs, capital expenditures and stock of capital, are required for cost efficiency analysis of firms. In addition, the main physical characteristics of the system need to be accounted for, namely, the length of network, transformers, units of electric energy delivered, system losses, maximum system simultaneous demand, and number and composition of the utilities' customers (Table VI.).

v. Welfare economic effects of reform vary across income groups, and ineffective regula tion prevents the gains from reform from being passed onto customers.

Reform and privatization are expected to lead to tangible benefits for consumers. However, in many developing countries there are indications that public acceptance of privatization programmes has declined in recent years (Lora and Panizza, 2002). This may be partly the result of ineffective regulatory frameworks for ensuring that customers benefit from efficiency improvements 
and that vulnerable income groups are protected. This type of question can be addressed through case studies involving cost-benefit analysis and distributional impacts. The main core indicators with reference to the components of our reform model are price and consumption data for income groups (Table IX), changes in access and quality of service (Table V), regulatory framework (Table IV), and where possible environmental impacts of reforms (Table X).

\subsection{Electricity sectors indicators}

\section{Sector endowments and characteristics}

\begin{tabular}{|c|c|c|c|}
\hline Focus area & Indicator & $\begin{array}{c}\text { Data Source } \\
\text { (UK as example) }\end{array}$ & Reference \\
\hline ? Resource mix & $\begin{array}{l}\text { ? Electricity generation mix: } \\
\text { (i) net generation capacity (MW) } \\
\text { (ii) energy supplied (MWh) } \\
\text { ? Primary energy supply mix (MTOE) }\end{array}$ & IEA and OECD & \\
\hline $\begin{array}{l}\text { ? Energy security and } \\
\text { resource independence } \\
\text { ? Reserve generation } \\
\text { capacity }\end{array}$ & $\begin{array}{l}\text { ? Electricity consumption, domestic } \\
\text { production, import, export (MWh) } \\
\text { ? Energy consumption, domestic production, } \\
\text { import, exports (MTOE). } \\
\text { ? Self-sufficiency in electricity - domestic } \\
\text { production GWh / domestic production + net } \\
\text { imports (\%) } \\
? \text { Energy self-sufficiency - domestic/total (\%) } \\
\text { ? Reserve capacity - at maximum demand } \\
\text { (MW, and as \% of total installed capacity) }\end{array}$ & & $\begin{array}{l}\text { Drillisch et al. } \\
\text { (1998) }\end{array}$ \\
\hline $\begin{array}{l}\text { ? Electricity and energy } \\
\text { consumption per capita }\end{array}$ & $\begin{array}{l}\text { Electricity consumption per capita } \\
\text { ? } \text { Energy consumption per head }\end{array}$ & & Zhang et al. (2002) \\
\hline ? Unserved demand & $\begin{array}{l}\text { ? Households without electricity (number } \\
\text { and \% of total) } \\
? \text { Non-commercial energy (amount) }\end{array}$ & & \\
\hline $\begin{array}{l}\text { ? Energy and electricity } \\
\text { intensity of GDP }\end{array}$ & $\begin{array}{ll}? & \text { Electricity use per GDP unit }(\mathbf{k W h} / \$) \\
? & \text { Energy use per GDP unit }(\mathrm{TOE} / \$)\end{array}$ & & Zhang et al. (2002) \\
\hline $\begin{array}{l}\text { ? Overall system price- } \\
\text { cost relationship }\end{array}$ & ? Price/cost (values per kWh, ratio) & & \\
\hline ? Number of customers & $\begin{array}{l}\text { No. of residential, industrial, and commercial } \\
\text { customers. customers }\end{array}$ & & \\
\hline $\begin{array}{l}\text { ? Natural gas (domestic } \\
\text { availability) }\end{array}$ & ? Proven reserves / annual production ratio & & \\
\hline
\end{tabular}




\begin{tabular}{|c|c|c|c|}
\hline \multicolumn{4}{|c|}{ II. Key Reform Steps } \\
\hline Focus area & Indicator & $\begin{array}{l}\text { Data Source } \\
\text { (e.g. UK) }\end{array}$ & $\begin{array}{l}\text { Source/reference } \\
\text { (example) }\end{array}$ \\
\hline ? Electricity law or act & ? Date of effectiveness (year) & Regulator's web-site & Bacon (1999) \\
\hline ? Corporatisation & $\begin{array}{l}\text { ? Are state-owned enterprises corporatised? } \\
\text { (no/yes-fully, partially) }\end{array}$ & Interviews & Bacon (1999) \\
\hline ? Privatisation & $\begin{array}{l}\text { ? Start date (year) } \\
\text { ? Privatisation proceeds from G, T, D } \\
\text { (national currency and US\$ per kW, MWh)* } \\
\text { ? Privatised electricity assets - G }(\mathrm{MW}), \mathrm{T} \\
\text { (MW), D (MWh) as \% of total }\end{array}$ & & $\begin{array}{l}\text { Zhang et al. (2002) } \\
\text { Siniscalco, et al. } \\
\text { (2001) } \\
\text { Bacon (1999) }\end{array}$ \\
\hline ? Unbundling & $\begin{array}{l}\text { ?ertical separation of G from T/D } \\
\text { (no/yes - legal, accounting, ownership) }\end{array}$ & & $\begin{array}{l}\text { Bacon (1999) } \\
\text { Steiner (2001) }\end{array}$ \\
\hline $\begin{array}{l}\text { ? Private sector } \\
\text { participation (new entry) }\end{array}$ & $\begin{array}{l}\text { Are new private concessions and } \\
\text { greenfield investments allowed? (no/yes) }\end{array}$ & & Bacon (1999) \\
\hline ? Retail competition & $\begin{array}{l}\text { ? Is retail competition allowed? (no/yes - } \\
\text { Down to what level? }\end{array}$ & & Bacon (1999) \\
\hline $\begin{array}{l}\text { ? Wholesale electricity } \\
\text { market }\end{array}$ & $\begin{array}{l}\text { ? Is a wholesale market established? (no/yes } \\
\text { - Pool, single-buyer, cost-based/price-based, } \\
\text { voluntary / compulsory participation, } \\
\text { demand participation, contract market } \\
\text { bilateral, forward), balancing, IPPs) }\end{array}$ & & $\begin{array}{l}\text { Zhang et al. (2002) } \\
\text { Steiner (2001) }\end{array}$ \\
\hline ? Regulator & $\begin{array}{l}\text { ? Is a regulator established? (no/yes - } \\
\text { independent, ministerial, other) }\end{array}$ & & $\begin{array}{l}\text { Zhang et al. (2002) } \\
\text { Bacon (1999) }\end{array}$ \\
\hline $\begin{array}{l}\text { ? Network regulatory } \\
\text { reform }\end{array}$ & $\begin{array}{l}\text { ? Is there incentive regulation for T } \\
\text { networks? (no/yes - price -cap, partial } \\
\text { incentive schemes, other) } \\
\text { ? Is there incentive regulation for D } \\
\text { networks? (no/yes - price -cap, partial } \\
\text { incentive schemes, other) }\end{array}$ & & \\
\hline $\begin{array}{l}\text { ? Composite reform } \\
\text { index }\end{array}$ & $\begin{array}{l}\text { ? Number of key reform steps taken } \\
\text { (alternatively weighted) }\end{array}$ & & $\begin{array}{l}\text { Bacon and Besant- } \\
\text { Jones (2002), } \\
\text { Drillisch et al. } \\
\text { (1998) }\end{array}$ \\
\hline
\end{tabular}




\section{Market Structure}

\begin{tabular}{|c|c|c|c|}
\hline Focus area & Indicator & $\begin{array}{l}\text { Data Source (e.g. } \\
\text { UK) }\end{array}$ & $\begin{array}{l}\text { Source/reference } \\
\text { (example })\end{array}$ \\
\hline $\begin{array}{l}\text { ? Degree of vertical } \\
\text { integration }\end{array}$ & $\begin{array}{l}\text { ? Energy delivered by vertically integrated } \\
\text { firms (own generation as \% of total demand) }\end{array}$ & $\begin{array}{l}\text { Questionnaire to } \\
\text { regulator }\end{array}$ & \\
\hline ? Number of firms & ? Number of G, T, D firms & & \\
\hline ? Ownership structure & $\begin{array}{l}\text { ? Private, local, government owned G, T, D } \\
\text { firms (size- MW/MWh, number of firms) }\end{array}$ & & Steiner (2001) \\
\hline ? Wholesale market & $\begin{array}{l}\text { ? Is there a wholesale generation market? } \\
\text { (no/yes - type: e.g. single-buyer, cost-based } \\
\text { pool, voluntary or compulsory pool } \\
\text { participation, demand-side participation, } \\
\text { bilateral/forward contract market, balancing } \\
\text { market, IPPs }\end{array}$ & & As above \\
\hline $\begin{array}{l}\text { ? Wholesale market } \\
\text { concentration }\end{array}$ & $\begin{array}{l}\text { ? Market share of } 1^{\text {st }} 5^{\text {th }} \text { largest generators } \\
\text { (as \% of total capacity). } \\
\text { ? HHI of generation firms (index) }\end{array}$ & & \\
\hline ? Access to networks & $\begin{array}{l}\text { ? Are there provisions for generators to } \\
\text { have access to transmission network? (no, yes } \\
\text { - rTPA, nTPA) }\end{array}$ & & Steiner (2001) \\
\hline $\begin{array}{l}\text { ? Retail market opening } \\
\text { ? Interconnections }\end{array}$ & $\begin{array}{l}\text { ? Degree of market opening (\% of total } \\
\text { consumption liberalised) } \\
\text { ? Threshold level for retail customer choice } \\
\text { (MW, MWh) } \\
\text { ? Retail competition (no., \% share of } \\
\text { independent suppliers in different market } \\
\text { segments) } \\
\text { ? Degree of switching from incumbent } \\
\text { suppliers (no. and \% of eligible customers) } \\
\text { ? Interconnections with other systems } \\
\text { (capacity, \% share of total market) }\end{array}$ & & Steiner (2001) \\
\hline $\begin{array}{l}\text { ? Independent Power } \\
\text { Producers (IPPS) }\end{array}$ & $\begin{array}{l}\text { ? Significance of IPPs (no., share, and type - } \\
\text { long-term contract, merchant) }\end{array}$ & & \\
\hline
\end{tabular}




\section{Regulation, Governance, and Institutions}

\begin{tabular}{|c|c|c|}
\hline Focus area & Indicator & $\begin{array}{c}\text { Data Source } \\
\text { (e.g. UK) }\end{array}$ \\
\hline $\begin{array}{l}\text { ? Establishment of } \\
\text { regulator }\end{array}$ & ? Start date of regulator (year) & $\begin{array}{l}\text { Questionnaire to } \\
\text { regulator and } \\
\text { interview }\end{array}$ \\
\hline $\begin{array}{l}\text { ? Network regulation } \\
\text { and price control }\end{array}$ & $\begin{array}{ll}\text { ? } & \text { T regulation (ROR, PCAP, other) } \\
\text { ? } & \text { D regulation (ROR, PCAP, other) } \\
? & \text { Length of price control period (years) } \\
\text { ? } & \text { Are there quality of service targets? (no/yes - type) }\end{array}$ & \\
\hline $\begin{array}{l}\text { ? Transmission network } \\
\text { access and system } \\
\text { operation }\end{array}$ & $\begin{array}{l}\text { ? Is third-party access to T networks? (no/yes - rTPA, nTPA) } \\
\text { ? Is TSO independent of network operator? (no/yes) }\end{array}$ & \\
\hline $\begin{array}{l}\text { ? Market structure } \\
\text { regulation }\end{array}$ & $\begin{array}{l}\text { Are there restrictions on vertical integration? (no/yes) } \\
? \text { Are there restrictions on horizontal integration? (no/yes) }\end{array}$ & \\
\hline ? Subsidies & $\begin{array}{l}\text { ? Are there cross-subsidies between residential, industrial and } \\
\text { service users? (no/yes - type) } \\
\text { ? Are there government-funded subsidies? (no/yes - type) }\end{array}$ & \\
\hline $\begin{array}{l}\text { ? Regulatory budget and } \\
\text { resources }\end{array}$ & $\begin{array}{l}\text { ? Annual budget size of regulator (amount) } \\
? \text { Source of regulatory funds (government, levies on companies, } \\
\text { customer levies, other) } \\
? \quad \text { Total and professional staff (no.) }\end{array}$ & \\
\hline $\begin{array}{l}\text { ? Regulator appointment } \\
\text { and dismissal }\end{array}$ & $\begin{array}{l}\text { ? Who appoints the regulator? (president, prime minister, } \\
\text { parliament) } \\
\text { ? How long is the regulator's term? (fixed term - years, unlimited_ } \\
\text { ? Can the regulator be re-appointed? (no/yes) } \\
\text { ? Which authority can dismiss the regulator (president, prime } \\
\text { minister, minister, parliament) }\end{array}$ & \\
\hline ? Regulatory decisions & $\begin{array}{l}\text { ?ho makes the final regulatory decisions? (a single head, board, } \\
\text { other) }\end{array}$ & \\
\hline ? Regional regulators & ? Are there regional regulators? (no/yes) & \\
\hline $\begin{array}{l}\text { ?Consultation and } \\
\text { transparency }\end{array}$ & $\begin{array}{l}\text { ? Is there an open consultation process prior to decisions? } \\
\text { (no/yes) } \\
\text { ? Are regulatory decisions open to the public? (no/yes) } \\
\text { ? Does the regulator publish hearings, decisions, and } \\
\text { explanations? (no/yes) } \\
\text { ? Does the regulator have a website? (no/yes) } \\
\text { ? Are consultation papers on the website? (no/yes) }\end{array}$ & \\
\hline ? Appeal & ? Can the regulator's decisions be appealed? (no, yes - to whom) & \\
\hline $\begin{array}{l}\text { ? Regulatory discretion } \\
\text { and mandate }\end{array}$ & $\begin{array}{l}\text { ? Can the regulator decide on prices? (no/yes) } \\
\text { ? Can the regulator decide award of G, T, and D permits/licences? } \\
\text { (no/yes) } \\
? \text { Is the regulator mandated to protect customers? (no/yes) } \\
? \text { Does the regulator have mandate and rules concerning } \\
\text { disconnection for non-payment? (no/yes) } \\
? \text { Are there other formal (government, consumer groups, etc.) bodies } \\
\text { in charge of customer protection? (no/yes - who) }\end{array}$ & \\
\hline
\end{tabular}




\begin{tabular}{|c|c|c|c|}
\hline \multicolumn{4}{|c|}{ V. Sector Performance } \\
\hline Focus area & Indicator & $\begin{array}{c}\text { Data Source (e.g. } \\
\text { UK) }\end{array}$ & $\begin{array}{c}\text { Source/reference } \\
\text { (example) }\end{array}$ \\
\hline $\begin{array}{l}\text { ? Technical and } \\
\text { physical performance }\end{array}$ & $\begin{array}{l}\text { ? Asset utilisation: system load factor } \\
\text { (electricity generation MWh / average } \\
\text { capacity MWx8760 as a percentage) } \\
\text { ? Labour productivity (net electricity } \\
\text { generation per employee MWh) } \\
\text { ? Plant availability factor (Load factor by } \\
\text { plant, i.e. electricity generation MWh / } \\
\text { average capacity MWx8760 ratio) } \\
\text { ? T system losses - technical and non- } \\
\text { technical losses (MWh, \%) } \\
\text { ? D system losses - technical and non- } \\
\text { technical losses (MWh, \%) } \\
\text { ? Electricity consumption per capita (KWh) } \\
\text { ? Generation capacity per capita (MW) } \\
\text { ? Reserve margin }\end{array}$ & $\begin{array}{l}\text { Regulator's } \\
\text { publications } \\
\text { Department of Trade } \\
\text { and Industry (DTI) } \\
\text { Questionnaire }\end{array}$ & $\begin{array}{l}\text { Zhang (2002) } \\
\text { Steiner (2001) }\end{array}$ \\
\hline ? Sector investments & $\begin{array}{l}\text { ? Domestic investments in G, T, D- } \\
\text { greenfield projects, privatised assets } \\
\text { (amounts) } \\
\text { ? Foreign investments in G, T, D- } \\
\text { greenfield and privatised assets (amounts) } \\
\text { ? Government investments in G, T, D } \\
\text { (amounts) } \\
\text { ? Foreign investments as \% of total foreign } \\
\text { direct investments (FDI) }\end{array}$ & & \\
\hline ? Quality of service & $\begin{array}{l}\text { ? Reliability of service (number of } \\
\text { interruptions) } \\
\text { ? Security of service (number of minutes lost } \\
\text { per customer) }\end{array}$ & & \\
\hline ? Non-payments & $\begin{array}{l}\text { ? Non-payment and foregone revenues } \\
\text { (amount, as \% of total electricity delivered, as \% } \\
\text { of total revenues }\end{array}$ & & \\
\hline ? System expansion & $\begin{array}{l}\text { ? Generation capacity growth (MW, as \% of } \\
\text { total) }\end{array}$ & & \\
\hline ? Prices & $\begin{array}{l}\text { ? End-user prices - residential, industrial, } \\
\text { commercial sectors with and without taxes } \\
\text { (price per KWh) } \\
\text { ? Ratio of industrial to residential prices }\end{array}$ & & \\
\hline
\end{tabular}




\begin{tabular}{|c|c|c|c|}
\hline \multicolumn{4}{|c|}{ VI. Firm -level indicators } \\
\hline Focus area & Indicator & $\begin{array}{c}\begin{array}{c}\text { Data Source } \\
\text { (e.g. UK) }\end{array} \\
\end{array}$ & $\begin{array}{c}\text { Source/reference } \\
\text { (example) }\end{array}$ \\
\hline ? Electric energy & $\begin{array}{ll}\text { ? } & \text { Total units of energy sold (MWh) } \\
? & \text { Domestic/industrial/commercial sale (MWh) } \\
\text { ? } & \text { Maximum demand }(\mathbf{M W}) \\
? & \text { Service area }(\mathrm{Sq} . \mathrm{km})\end{array}$ & $\begin{array}{l}\text { Company annual } \\
\text { reports and } \\
\text { regulatory accounts. } \\
\text { Regulator's } \\
\text { publications. }\end{array}$ & $\begin{array}{l}\text { Pardina and Rossi } \\
(2000)\end{array}$ \\
\hline ? Customers & $\begin{array}{ll}? & \text { Total no. of customers } \\
? & \text { No. residential/non-residential customers }\end{array}$ & & $\begin{array}{l}\text { Jamasb and Pollitt } \\
\text { (2003) }\end{array}$ \\
\hline ? Networks & 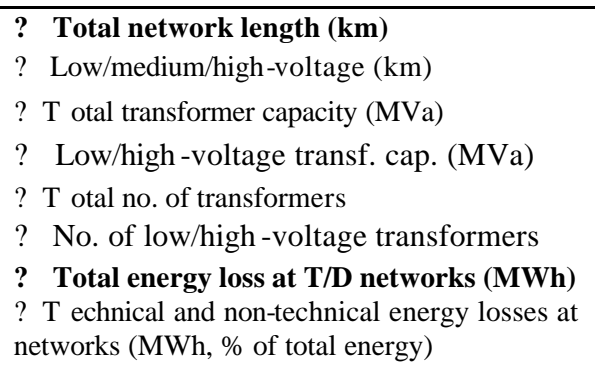 & & $\begin{array}{l}\text { Jamasb and Pollitt } \\
(2003)\end{array}$ \\
\hline ? Quality of service & $\begin{array}{ll}\text { ? } & \text { Security of service (no. of minutes lost) } \\
\text { ? } & \text { Reliability of service (no. of interruptions) }\end{array}$ & & $\begin{array}{l}\text { Giannakis et al. } \\
\text { (2003) }\end{array}$ \\
\hline ? Costs and revenues & $\begin{array}{ll}\text { ? } & \text { Total costs (value) } \\
\text { ? } & \text { Controllable O\&M costs (value) } \\
\text { ? } & \text { Labour costs (value) } \\
\text { ? } & \text { Annual capital expenditures (value) } \\
? & \text { Electricity capital stocks (value) } \\
? & \text { Revenues from electricity sales (value) } \\
? & \text { Net margin (net earnings/revenue \%) } \\
? & \text { Corporate capital employed (value) }\end{array}$ & & $\begin{array}{l}\text { Jamasb and Pollitt } \\
(2003) \\
\text { Delmas et al. (2003) }\end{array}$ \\
\hline ? Power generation & $\begin{array}{ll}\text { ? } & \text { Generation capacity - by fuel type (MW) } \\
\text { ? } & \text { Energy production - by fuel type (MWh) } \\
\text { ? } & \text { Load factor (avg. load MW/ capacity MW) } \\
\text { ? } & \text { Electricity sold to other utilities (MWh) } \\
? & \text { Purchased power from other utilities (MWh) }\end{array}$ & $\begin{array}{l}\text { Company annual } \\
\text { reports } \\
\text { Department of Trade } \\
\text { and Industry }\end{array}$ & $\begin{array}{l}\text { Arocena et al. (1999) } \\
\text { Hattori (1999) }\end{array}$ \\
\hline
\end{tabular}




\section{5}

\begin{tabular}{|c|c|c|c|}
\hline \multicolumn{4}{|c|}{ VII. Macro-Level Indicators } \\
\hline Focus area & Indicator & $\begin{array}{c}\text { Data Source (e.g. } \\
\text { UK) }\end{array}$ & $\begin{array}{c}\text { Source/reference } \\
\text { (example) }\end{array}$ \\
\hline$? G D P$ & ? GDP per capita & OECD & $\begin{array}{l}\text { Bacon and Besant- } \\
\text { Jones (2002) }\end{array}$ \\
\hline ? Energy intensity & $\begin{array}{l}\text { ? } \text { Electricity use per unit of GDP } \\
? \text { Energy use per unit of GDP }\end{array}$ & $\begin{array}{l}\text { IEA Statistics: } \\
\text { World Energy } \\
\text { Statistics }\end{array}$ & See above \\
\hline $\begin{array}{l}\text { ? Economic } \\
\text { liberalisation }\end{array}$ & $\begin{array}{l}\text { ? Has liberalisation been implemented in } \\
\text { other infrastructure industries? (no/yes - e.g. } \\
\text { natural gas, telecom, transport, railway) }\end{array}$ & & See above \\
\hline ? Country risk & ? Country risk index & & $\begin{array}{l}\text { Bacon and Besant- } \\
\text { Jones (2002) }\end{array}$ \\
\hline $\begin{array}{l}\text { ? Institutional } \\
\text { endowment }\end{array}$ & $\begin{array}{l}\text { ? Institutional and political strength - e.g. } \\
\text { Judiciary independence, economic } \\
\text { management, corruption indices }\end{array}$ & & $\begin{array}{l}\text { Bergara et al. (1997) } \\
\text { Kaufmann et al. } \\
(1999 a, 1999 b)\end{array}$ \\
\hline $\begin{array}{l}\text { ? Foreign aid and } \\
\text { economic dependence }\end{array}$ & $\begin{array}{ll}\text { ? } & \text { Foreign aid share of GDP (ratio) } \\
\text { ? } & \text { Degree of economic freedom (index) }\end{array}$ & & $\begin{array}{l}\text { Bacon and Besant- } \\
\text { Jones (2002) } \\
\text { Zhang (2002) } \\
\end{array}$ \\
\hline ? Human capital & $\begin{array}{ll}? & \text { literacy rate }(\%) \\
? & \text { Post-secondary education }(\%)\end{array}$ & & $\begin{array}{l}\text { e.g. World Bank } \\
\text { competitiveness } \\
\text { indicators } \\
\text { Domah et al. (2002) }\end{array}$ \\
\hline
\end{tabular}

5.6

\section{Economic impacts}

\begin{tabular}{|l|l|l|l|}
\hline \multicolumn{1}{|c|}{ Focus area } & \multicolumn{1}{|c|}{ Indicator } & $\begin{array}{c}\text { Data Source (e.g. } \\
\text { UK) }\end{array}$ & $\begin{array}{l}\text { Source/reference } \\
\text { (example) }\end{array}$ \\
\hline ? Relative prices & ? Ratio of industrial to residential prices & $\begin{array}{l}\text { Regulator's } \\
\text { publications }\end{array}$ & $\begin{array}{l}\text { Steiner (2001) } \\
\text { Hattori (2003) }\end{array}$ \\
\hline ? Subsidies & $\begin{array}{l}\text { ? Are there cross-subsidies between } \\
\text { residential, industrial and service users? (no/yes) } \\
\text { ? Are there public subsidies? (no, yes-amount) }\end{array}$ & $\begin{array}{l}\text { Department of Trade } \\
\text { and Industry (DTI) }\end{array}$ & \\
\hline $\begin{array}{l}\text { ? Investments in the } \\
\text { sector }\end{array}$ & $\begin{array}{l}\text { ? Private and Government investments in G, } \\
\text { T, D (amounts) } \\
\text { ? Government investments in G, T, D (as \% } \\
\text { of total public budget \& investments) }\end{array}$ & & \\
\hline ? Efficiency gains & $\begin{array}{l}\text { ? Estimated efficiency gains (as \% of GDP) } \\
\end{array}$ & & $\begin{array}{l}\text { Chisari et al. (1997) } \\
\text { Bacon and Besant- } \\
\text { Jones (2002) }\end{array}$ \\
\hline
\end{tabular}




\section{Social impacts}

\begin{tabular}{|c|c|c|c|}
\hline Focus area & Indicator & $\begin{array}{c}\text { Data Source } \\
\text { (e.g. UK) }\end{array}$ & $\begin{array}{c}\text { Source/reference } \\
\text { (example) }\end{array}$ \\
\hline ? Consumer prices & $\begin{array}{l}\text { ? End-user prices - Avg. residential, } \\
\text { industrial, commercial prices with and } \\
\text { without taxes (per KWh) } \\
\text { ? Price levels for different income groups (\%) } \\
\text { ? Consumption levels for different income } \\
\text { groups (MWh) } \\
\text { ? Expenditures on electricity for different } \\
\text { income groups } \\
\text { ? Ratio of daily disposable income for } 20 \% \\
\text { poorest income groups to price of electricity }\end{array}$ & $\begin{array}{l}\text { IEA Statistics: } \\
\text { Energy Price and } \\
\text { Taxes } \\
\text { IEA Statistics: } \\
\text { World Energy } \\
\text { Statistics } \\
\text { Surveys }\end{array}$ & $\begin{array}{l}\text { Delfino and Casarin } \\
\text { (2001) } \\
\text { Torero and Pascó- } \\
\text { Font (2003) } \\
\text { IAEA -IEA (2002) }\end{array}$ \\
\hline ? Economic welfare & $\begin{array}{l}\text { ? Welfare effect among income groups } \\
\text { ? Welfare distribution effect among } \\
\text { government, consumers, producers }\end{array}$ & & $\begin{array}{l}\text { Ennis and Pinto } \\
\text { (2002) } \\
\text { Mota (2003) }\end{array}$ \\
\hline ? Access to service & $\begin{array}{l}\text { ? Level of electrification (n o., \% of total } \\
\text { households connected) } \\
\text { ? Rate of change in electrification (no. of new } \\
\text { connections) } \\
\text { ? Level of urban electrification (no., \% of total } \\
\text { urban households connected) } \\
\text { ? Level of rural electrification (no., \% of total } \\
\text { rural households connected) }\end{array}$ & & \\
\hline ? Energy use & $\begin{array}{l}\text { Electricity consumption per capita (KWh) } \\
\text { ? Commercial energy use per capita (KWh, } \\
\text { annual growth rate \%) } \\
\text { ? Share non- commercial energy as total energy } \\
\text { consumption }(\%)\end{array}$ & & $\begin{array}{l}\text { Bacon and Besant- } \\
\text { Jones (2002) }\end{array}$ \\
\hline ? Continuity of service & ? Dis-connections from service (no.) & & \\
\hline
\end{tabular}

\section{Environmental impacts}

\begin{tabular}{|c|c|c|c|}
\hline Focus area & Indicator & $\begin{array}{l}\text { Data Source } \\
(\text { e.g. UK) }\end{array}$ & $\begin{array}{c}\text { Source/reference } \\
\text { (example) }\end{array}$ \\
\hline ? Climate change & $\begin{array}{l}\text { ? } \mathrm{CO}_{2} \text { emissions by the sector }(\mathbf{0 , 0 0 0} \text { tones) } \\
\text { ? Rate of change in } \mathrm{CO}_{2} \text { emissions by the } \\
\text { sector }(\%) \\
\text { ? } \mathrm{CO}_{2} \text { intensity of the sector (' } 000 \\
\text { tones/MWh) }\end{array}$ & $\begin{array}{l}\text { IEA Statistics: } \mathrm{CO}_{2} \\
\text { Emissions from Fuel } \\
\text { Combustion } \\
\text { National Statistics } \\
\text { Online }\end{array}$ & \\
\hline ? Polluting emissions & $\begin{array}{l}\text { ? } \mathrm{SO}_{2}, \mathrm{NO}_{\mathbf{x}} \text {, particulates, CO, VOC } \\
\text { emissions by the sector (quantity) } \\
\text { ? Rate of change in } \mathrm{SO}_{2}, \mathrm{NO}_{x} \text {, particulates, } \\
\mathrm{CO}, \mathrm{VOC} \text { emissions by the sector }(\%) \\
\text { ? Concentration levels of } \mathrm{SO}_{2}, \mathrm{NO}_{\mathrm{x}} \text {, } \\
\text { particulates, } \mathrm{CO}, \mathrm{VOC} \text { in urban areas (values) }\end{array}$ & $\begin{array}{l}\text { Department for } \\
\text { Environment, Food } \\
\text { and Rural Affairs: } \\
\text { Digest of } \\
\text { Environmental } \\
\text { Statistics }\end{array}$ & IAEA -IEA (2002) \\
\hline
\end{tabular}




\section{Summary and directions for the future}

This paper develops a framework and proposes a set of core indicators for electricity sector reform. Empirical research is currently limited, and existing evidence is rather fragmented and based on a variety of model specifications, variable definitions and types of data. Having a shared set of core indicators will contribute to research and policy making by facilitating verification and extension of results from other studies. The indicators can be used in general purpose monitoring of reform progress, as well as in empirical studies using econometric, efficiency and case study analysis of individual countries and cross-country comparisons.

In the first instance, mapping the main sources of data can follow the proposed framework and indicators as some of these will be readily available from open sources. A glance at the tables in section 5.3 suggests that most of the data under sector endowments and characteristics (Table I), macro-level indicators (Table VII) and environmental impacts (Table $\mathrm{X}$ ) is available at the country level. It also appears that significant amounts of data have been collected on key reform steps (Table II), market structure (Table III), regulation, governance and institutions (Table IV) and economic impacts (Table VIII). However, the data needs to be regularly updated and there does not seem to have been a sustained effort at the level of the World Bank and other international development and finance organisations to do this.

The areas where most work on data collection, extension and standardisation needs to be done would appear to be on sector performance indicators (Table V) and firm-level indicators (Table VI). Data for some of the missing indicators may be collected with relative ease through surveys, and the proposed framework described in this paper facilitates the design of such surveys. For some indicators, the practicality of collecting the data needs to be assessed given the significant potential collection cost; some of the 
social impact indicators under Table IX, suc h as welfare effects among income groups, may be extremely time consuming to collect on a consistent basis.

As in some other areas of social and economic studies, data collection work can be initiated by relevant international organisations and can then be carried forward through co-operation with other international and national bodies. The International Energy Agency (IEA), the US Department of Energy's Energy Information Administration (EIA), the Latin American Energy Organisation (OLADE) and the African Energy Policy Research Network (AFREPREN) provide a good starting point for international energy data. Due to the dynamic nature of electricity reform it is important that data is collected on a consistent, ongoing basis.

Not all data will be available for all countries in all years but this does not necessarily mean that the process cannot begin. Existence of a shared framework and co-ordinated effort is a first step and an incentive to join such an effort or to integrate them into the existing data collection programs. Costs and required resources are justified by the social and economic importance of the electricity sector. Electricity reforms can have a significant effect on many development goals (such as contained in the Millennium Development Goals ${ }^{3}$ ) that are directly or indirectly dependent on developing sustainable energy systems in developing countries.

We tentatively suggest the following strategy for World Bank data collection in order to build a comprehensive resource base on electricity sector reforms:

i. Agree a list of desirable indicators and countries,

ii. Begin a search and summarise the main published (international) data resources,

iii. Conduct a systematic search of internal World Bank resources e.g. by collecting latest country mission reports on energy sector,

iv. Make inventory of missing data and countries,

\footnotetext{
${ }^{2}$ Although welfare impacts would seem to be extremely important we do not highlight these as core indicators because of the difficulty of collection.

${ }^{3}$ See http://www.developmentgoals.org/
} 
v. Begin detailed search of national sources e.g. ministries of energy, industry, and regulatory agencies,

vi. Agree on required data after looking at all published sources,

vii. Draft questionnaire for survey of energy ministries and regulators,

ix. Collate final results,

x. Post data base on the Internet when finalised,

xi. Solicit voluntary contributions and updates from authorities, organisations, and companies, and

xii. Review, maintain, and update periodically. 


\section{References}

Arocena, P. and Waddams-Price, C. (2002). "Generating Efficiency: Economic and Environmental Regulation of Public and Private Electricity Generators in Spain", International Journal of Industrial Organization, Vol. 20, No. 1, pp. 41-69.

Atkinson, T., Cantillon, B., Marlier, E., and Nolan, B. (2002). "Social Indicators: The EU and Social Inclusion”, Oxford University Press: New York.

Bacon, R. (1999). “A Scorecard for Energy Reform in Developing Countries”, Public Policy for the Private Sector, Note No. 175, April, The World Bank, Washington, DC.

Beato, P. and Laffont, J. J. (2002). "Competition in Public Utilities in Developing Countries", Sustainable Development Department, Technical Papers Series, 2/02, IFM-127, Inter-American Development Bank, Washington DC.

Bergara, M., Henisz, W. J. and Spiller, P. T. (1997). "Political Institutional and Electric Utility Investment: A Cross-Nation Analysis", Program on Workable Energy Regulation (POWER), Working Paper No. PWP-052, University of California Energy Institute, University of California at Berkeley.

Bossel, H. (1999). "Indicators for Sustainable Development: Theory, Method, Applications”, International Institute for Sustainable Development (IISD), Winnipeg, Manitoba, Canada.

CAEM (2003). "Electricity Retail Energy Deregulation Index 2003”, Fourth Edition of the Electricity RED Index, A Scorecard for Measuring Progress on Energy Restructuring, Center for the Advancement of Electricity Markets (CAEM), April. 
Chisari, O., Estache, A., and Romero, C. (1997). "Winners and Losers from Utility Privatization in Argentina: Lessons form a General Equilibrium Model”, World Bank Policy Research Working Papers 1824, September, World Bank, Washington, D.C.

Delfino, J. A. and Casarin, A. A. (2001). "The Reform of the Utilities Sector in Argentina", World Institute for Development Economics Research (WIDER), Discussion Paper DP No. 2001/74.

Delmas, M. and Tokat, Y. (2003). "Deregulation Process, Governance Structures and Efficiency: The U.S. Electric Utility Sector", Energy Policy and Economics No. 4, University of California Energy's Institute (UCEI), Berkeley, California.

Domah, P., Pollitt, M.G. and Stern, J. (2002). "Modelling the Costs of Energy Regulation: Evidence of Human Resource Constraints in Developing Countries" Department of Applied Economics Working Papers CMI EP 11, University of Cambridge.

Drillisch, J. and Riechmann, C. (1998). "Liberalisation of the Electricity Supply Industry - Evaluation of Reform Policies”, EWI Working Paper 98/5, Cologne/ Tokyo, December 1998.

DTI (2000). "Energy Liberalisation Indicators in Europe", Department of Trade and Industry (DTI), October, London.

EBRD (2001). “Transition Report 2001: Energy in Transition”, European Bank for Reconstruction and Development (EBRD), November, London.

Ennis, H. M., Pinto, S. M. (2002). "Privatization and Income Distribution in Argentina", paper presented at the Center for Global Development Conference on Privatisation and Income Distribution, February. Weblink: http://www.cgdev.org/events/privatization/EnnisPinto_Argentina_paper.pdf 
Giannakis, D., Jamasb, T., and Pollitt, M. (2003). "Benchmarking and Incentive Regulation of Quality of Service: An Application to the UK Electricity Distribution Utilities", CWPE/DAE Working Paper, Department of Applied Economics, University of Cambridge (forthcoming).

Harris, C. (2003) "Private Participation in Deve loping Countries: Trends, Impacts, and Policy Lessons", World Bank Working Paper No. 5, The World Bank, Washington D.C.

IADB (2001). "Competitiveness: The Business of Growth, Economic and Social Progress in Latin America", Research Department, Inter-American Development Bank (IADB), Washington, D.C.

IEA (2003a). "Key World Energy Statistics”, International Energy Agency (IEA), Paris.

IEA (2003b). “Electricity Information 2003”, International Energy Agency (IEA), Paris.

IAEA-IEA (2002). "Indicators for Sustainable Energy Development", paper presented at Commission on Sustainable Development, 9th Session (UNCSD-9), New York, 16-27 April 2001, International Atomic Energy Agency (IAEA), Vienna and International Energy Agency (AEA), Paris.

Weblink: http://www.iea.org/envissu/files/csd-9.pdf

Jamasb, T., Mota, R., Newbery, D., and Pollitt, M. (2004). "Electricity Sector Reform in Developing Countries: A Survey of Empirical Evidence on Determinants and Performance", Cambridge Working Papers in Economics, Department of Applied Economics, University of Cambridge (forthcoming).

Jamasb, T, Pollitt, M. (2003). "International Benchmarking and Yardstick Regulation: An Application to European Electricity Utilities”, Energy Policy 31(15). 
Joskow, P. L. (1998). "Electricity Sectors in Transition”, The Energy Journal, Vol. 19, No. 2, pp. 25-52.

Hattori, T. (1999). "Parametric Tests of Cost Efficiency for Japanese Electric Utilities: Before and After the Regulatory Reform in 1995", mimeo.

Kaufmann, D., Kraay, A., and Zoido-Lobaton, P. (1999a). "Governance Matters", World Bank Working Paper \#2196, The World Bank, Washington D.C.

Kaufmann, D., Kraay, A., and Zoido-Lobaton, P. (1999b). “Aggregating Governance Indicators”, World Bank Working Paper \#2195, The World Bank, Washington D.C.

Leamer, E. E. (1983). "Let's Take the Con Out of Econometrics", The American Economic Review, Vol. 73, No. 1, March, 31-43.

Leamer, E. E. (1985). "Sensitivity Analysis Would Help", The American Economic Review, Vol. 75, No. 3, June, 308-313.

Lora, E., Panizza, U. (2002). "Structural Reforms in Latin America under Scrutiny", Seminar Paper, Research Department, Inter-American Development Bank, April, Washington, D.C.

Mota, R. (2003), “The Restructuring and Privatisation of Electricity Distribution and Supply Business in Brazil: A Social Cost-Benefit Analysis”, DAE Working Paper 309, Department of Applied Economics, University of Cambridge, January.

Mukherjee, C., While, H., and Wuyts, M. (1998). "Econometrics and Data analysis for Developing Countries", Routledge, London.

Newbery, D. M. (2002). "Issues and Options for Restructuring Electricity Supply Industries", Working Paper CMI EP 01/DAE 0210, Department of Applied Economics, University of Cambridge. 
OECD (2002). “OECD Environmental Indicators: Towards Sustainable Development 2001”, Organisation for Economic Cooperation and Development (OECD), Paris.

OECD (1993). "OCED Core Set of Indicators for Environmental Performance Reviews" (Environmental Monograph 83), Paris.

Pardina, M. R. and M. Rossi (2000). "Technical Change and Catching-up: The Electricity Distribution Sector in South America", Working Paper No. 11 (November), Centro de Estudios Económicos de la Regulación, Departamento de Economía y Finanzas, Universidad Argentina de la Empresa.

Torero, M., A. Pascó-Font (2003). "The Social Impact of Privatization and The Regulation of Utilities in Peru", in Ugaz and Waddams-Price (eds.), "Utility Privatization and Regulation”, Edward Elgar, Cheltenham.

UN (2001). 'Indicators of Sustainable Development: Guidelines and Methodologies", Division for Sustainable Development, Department of Economic and Social Affairs, United Nations. Weblink: http://www.un.org/esa/sustdev/natlinfo/indicators/isd.htm

von Schrinding, Y. (2002). "Health in Sustainable Development Planing: The Role of Indicators", World Health Organisation (WHO), Geneva.

WRI (2002). "Power Politics: Equity and Environment in Electricity Reform”, World Resources Institute (WRI), Washington, D.C.

Zelner, B. A. and Henisz, W. J. (2000). "Political Institutions, Interest Group Competition and Infrastructure Investment in The Electric Utility Industry: A CrossNational Study", Working Paper WP No. 00-03, Reginald H. Jones Center, The Wharton School, University of Pennsylvania. 